\title{
PROFESI ARSITEK DI ERA GLOBALISASI
}

\author{
MUNICHY B. EDREES, IAI, AA
}

(Ketua Kehormatan IAI Nasional)

\begin{abstract}
Intisari
Keberadaan profesi arsitek sangat erat sekali dengan perkembangan sejarah dan peradaban manusia. Hubungan antara profesi arsitek dengan sejarah dan peradaban manusia dapat kita lihat dari pola rancang bangun yang mengalami perkembangan seiring dengan perkembangan peradaban manusia. Sejarah dan peradaban manusia di tiap negara satu dengan yang lain berbeda-beda, hal ini membawa keberagaman dalam perkembangan ilmu arsitektur. Indonesia adalah Negara yang terdiri atas ribuan pulau, ratusan bahasa, suku bangsa dan budaya. Memiliki budaya arsitektur yang beraneka ragam. Budaya itu ditunjukkan dari keberagaman rumah adat, lingkungan adat, dan penggunaan material-material pendukung dalam pembangunan pemukiman/hunian adat.
\end{abstract}

Kata kunci: Arsitek, Globalisasi

\section{PENDAHULUAN}

Keberadaan profesi arsitek sangat erat sekali dengan perkembangan sejarah dan peradaban manusia. Hubungan antara profesi arsitek dengan sejarah dan peradaban manusia dapat kita lihat dari pola rancang bangun yang mengalami perkembangan seiring dengan perkembangan peradaban manusia. Sejarah dan peradaban manusia di tiap negara satu dengan yang lain berbeda-beda, hal ini membawa keberagaman dalam perkembangan ilmu arsitektur.

Indonesia adalah Negara yang terdiri atas ribuan pulau, ratusan bahasa, suku bangsa dan budaya. Memiliki budaya arsitektur yang beraneka ragam. Budaya itu ditunjukkan dari keberagaman rumah adat, lingkungan adat, dan penggunaan materialmaterial pendukung dalam pembangunan pemukiman/hunian adat. Sekarang ini dalam menghadapi era globalisasi dan deferensiasi pasar bebas Masyarakat Ekonomi Asean (MEA), khasanah arsitektur Indonesia berusaha mengangkat keragaman etnik Indonesia dalam model desain yang bertemakan nuansa etnik yang menjadi suatu cirri orisionalitas langgam arsitektur nusantara yang membedakan dengan langgam atau gaya arsitektur impor. Arsitektur tidak hanya berbicara mengenai rancangan atau desain bangunan yang dilihat dari sisi keindahannya saja, akan tetapi ada 6 (enam) aspek yang dapat dilihat, yaitu : aspek fungsi, aspek bentuk/keindahan, aspek struktur/kekuatan, aspek keamanan dan keselamatan bangunan, aspek kenyamanan dan aspek kontekstual dimana bangunan akan didirikan.

Keberadaan profesi arsitek dan arsitektur secara resmi diatur dalam Undang-undang No. 8 tahun 1999 tentang Jasa Konstruksi, Undang-undang No. 28 tahun 2002 tentang Bangunan Gedung dan Undang-undang no. 11 tahun 2014 tentang Keinsinyuran. Namun hingga sekarang ini belum ada payung hukum yang bersifat lex spesialis yang melindungi dan memayungi keberadaan profesi arsitek. Kondisi inilah yang mendorong perlunya pengaturan lebih lanjut mengenai profesi arsitek, terutama dalam menghadapi Masyarakat Ekonomi Asean, liberalisasi sektor jasa ASEAN dan pasar bebas di tingkat global.

Yang menjadikan keprihatinan kita adalah bahwa Indonesia itu satu-satunya negara anggota ASEAN yang belum mempunyai Undang-undang Arsitek. Sekarang ini RUU Ar sudah masuk prolegnas DPR RI dengan harapan UUAr akan disyahkan pada Agustus 2017.

\section{ISI PENELITIAN}

\subsection{Apa Dan Bagaimana Arsitektur Itu.}

Arsitektur di Indonesia selama ini masih lebih banyak hanya dilihat dari sisi produknya saja. Produk yang dihasilkan melalui proses pemilihan perencana dan menjamin bahwa akan dikerjakan dengan baik dan hasilnya akan diukur sebagai komoditi yang harus dijaga sampai puluhan tahun, masih dianggap seperti produk-produk biasa yang dapat diperjualbelikan begitu saja. Padahal arsitek bekerja bukan dan tidak sekedar untuk kepentingan klien saja, melainkan terutama untuk "ultimate client" yaitu masyarakat luas. Setiap rancangan yang dibuat selalu dipertimbangkan dengan baik agar hasilnya membawa manfaat bagi kepentingan masyarakat luas.

Arsitektur sebagai suatu karya seni yang hanya bisa dicapai dengan dukungan masyarakat luas, hal ini berbeda dengan karya seni lain seperti seni lukis atau seni patung yang bisa tercipta hanya dengan usaha satu orang saja. Arsitektur adalah kesatuan bentuk dan fungsi atas hubungan yang logic dengan lingkungannya serta melestarikan dan mengembangkan ketrampilan tradisional dan hubungan-hubungan yang esensial dengan akarnya 
arsitektur sebagai manifestasi spiritual masyarakatnya (Henry Mc Pont).

Arsitektur sebagai suatu seni dan bangunan dari budaya dinyatakan secara jelas dalam sikap bangsa Indonesia, yang melalui Undang-undang tentang Cagar Budaya; maupun peraturan perundangundangan lainnya jelas-jelas wajib melindungi, merawat, merelokasi bahkan mengadaptasi sebagai peninggalan bersejarah budaya bangsa Indonesia. Dalam hal ini jelas hanya arsitek yang memiliki peran paling penting menjadi karya seni budaya tersebut, bahkan dalam aturan organisasinya juga dinyatakan akan menindak tegas arsitek yang dalam melakukan profesinya tidak mengindahkan keberadaan bangunan-bangunan dan lingkungan bernilai sejarah dan dilindungi.

Demikian juga didalam kegiatan perancangan arsitektur dan fasilitas ruang yang bersifat umum, arsitek harus memikirkan masalah-masalah keselamatan pemakai bila terjadi musibah pada bangunan dan lingkungannya, termasuk menyediakan sarana bagi orang lanjut usia dan orang berkebutuhan khusus. Karena kelalaian menyediakan sarana tersebut dapat menjadi kesalahan berakibat fatal yang bisa ditimpakan kepada arsitek sebagai perancang.

Arsitektur sebagai proses menciptakan ruang dan lingkungannya (alami/buatan). Tujuan proses perancangan adalah menafsirkan dan menjawab kebutuhan-kebutuhan manusia, menghasilkan pelayanan/fasilitas dan bentuk yang mempertimbangkan nilai-nilai budaya.

Masalah utama arsitektur sekarang ini tidak lagi pada permainan massa-massa dan space saja secara visual, akan tetapi penciptaan ruang-ruang tempat manusia beraktifitas, apakah tidak merugikan manusia lain atau lingkungan hidup lainnya termasuk potensi sumber daya alam maupun akar kearifan budaya local yang harus dilestarikan. Karena itu keahlian arsitek lah yang dianggap mampu melakukan hal tersebut, untuk menjadikan karya-karya arsitektur lebih baik dan memberikan nilai tambah bagi kehidupan manusia dan lingkungannya. Oleh karena itu keahlian di bidang arsitektur senantiasa menjadi ujung tombak suatu proses pembangunan, dan memiliki peran sangat penting dan menuntut peningkatan agar mampu menghadapi perubahan strategis persoalan pembangunan yang akan terus terjadi.

Harus diakui bahwa peran arsitek bersama keahlian terkait lainnya telah terbukti memiliki andil dalam memberikan hasil pembangunan di berbagai pelosok perkotaan dan di berbagai daerah menjadi lebih maju, sehingga sudah selayaknya pula profesi arsitek juga bisa lebih tersebar keseluruh daerah dan mendapatkan pengakuan dalam kontribusi Negara sebagaimana peran profesi lainnya seperti dokter, advokat, akuntan, notaris, dosen, dan guru, agar bisa menghasilkan karya-karya yang lebih bermanfaat bagi pengguna jasa.

Arsitektur sebagai wadah yang mewadahi kegiatan manusia, sehingga didalam merancang menempatkan 'manusia" sebagai parameternya. Karena didalam diri manusia itu ada 4(empat) aspek yang perlu dipertimbangkan, yaitu : 1. Aspek Biologis, 2. Aspek Psikologis, 3. Aspek Sosial dan 4. Aspek Akal Budi. Jikalau 4 aspek tadi dipenuhi dalam konsep rancangannya niscaya akan didapatkan hasil karya arsitektur yang ideal.

Arsitektur juga merupakan produk kreatif yang dapat diintegrasikan dengan peningkatan ekonomi masyarakat, dan dapat menjadi income generator bagi wisatawan secara keseluruhan.

Arsitektur harus mampu memberikan keunikan yang kontekstual terhadap budaya dan lokasitas setempat. Karena arsitektur yang unik mempunyai daya tarik tersendiri bagi lingkungannya maupun bagi wisatawan. Arsitektur harus mampu memberikan keunikan yang kontekstual terhadap lingkungan.

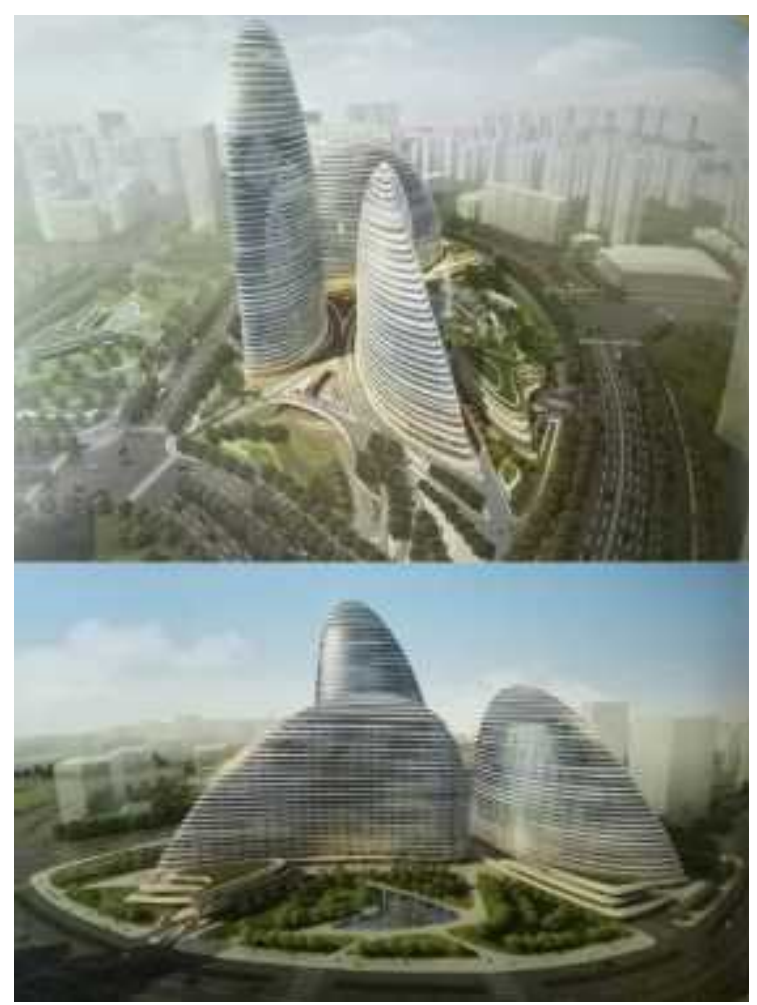

Gambar.1 Karya Arsitek

\subsection{Apa Dan Siapa Arsitek Itu}

Arsitek merupakan profesi yang spesifik, karena dalam melakukan praktik arsitektur harus mampu menangkap suatu pesan atau keinginan dari pengguna jasa untuk diwujudkan menjadi suatu karya berupa bangunan gedung beserta lingkungan binaan di sekitarnya yang fungsional, indah, kuat, aman, nyaman dan mampu beradaptasi dengan lingkungannya. Menciptakan desain dari yang belum pernah ada menjadi ada. Arsitek adalah suatu 
keahlian yang tidak mudah dilakukan oleh semua orang tanpa dasar pendidikan dan praktik yang memadai. Arsitek di dalam melakukan profesinya selain harus melayani keinginan pengguna jasanya juga harus memperhatikan kondisi lingkungan sekitarnya sebagai lokasi/site dimana arsitektur tersebut akan dibangun.

Sifat kerja arsitek yang spesifik sebagai penyedia jasa konstruksi di bidang arsitektur yang mencakup perancangan kota, arsitektur bangunan dan lingkungan binaan, lazimnya seperti di Negara lain diatur terpisah dari penyedia jasa lain, misal bidang keinsinyuran (engineering) seperti ahli konstruksi, ahli mekanikal dan elektrikal atau pelaksana bangunan/kontraktor. Kesalahkaprahan dalam pemberian gelar akademik bagi sarjana arsitektur yang sebagian juga menggunakan gelar insinyur seakan menyederhanakan ruang lingkup dan tanggung jawab masing-masing keahlian sama rata yang sesungguhnya berbeda-beda.

Bidang kearsitekturan telah jelas mengatur dirinya sebagai ahli bidang arsitektur dengan sebutan 'Arsitek', yaitu bila lulusan pendidikan tinggi arsitektur yang diakui pemerintah dan terakreditasi, telah dinyatakan kompeten berpraktik dalam bidang arsitektur dan memiliki Sertifikat Keahlian (SKA).

Dunia arsitektur Indonesia saat ini tengah menghadapi tantangan berat, khususnya pada saat Masyarakat Ekonomi ASEAN (MEA) diberlakukan pada akhir 2015 mendatang. Para arsitek professional diprediksi akan menghadapi persaingan antara arsitek local dan arsitek dari Negara-negara ASEAN. Arsitek Indonesia yang sudah tersertifikasi hanya sekitar 3000 orang.

ASEAN Mutual Recognition Arrangement (MRA) untuk jasa arsitek ditandatangani pada tanggal 19 November 2007 di Singapura. Tujuan dari MRA ini dijelaskan dalam 4 (empat) poin, yaitu :

1. Memfasilitasi mobilitas arsitek.

2. Melakukan pertukaran informasi dalam upaya mempromosikan pengadopsian best practices dalam hal standar pendidikan arsitektur, praktik profesional dan kualifikasi-kualifikasi lainnya.

3. Melaksanakan spirit kerjasama ASEAN yang menekankan pada distribusi sumber daya yang fair dan benefit melalui kolaborasi.

4. Mendorong, memfasilitasi dan membangun pengakuan timbal balik dalam hal jasa arsitek dan menyusun standard dan komitmen untuk melakukan transfer teknologi diantara Negaranegara anggota ASEAN.

Apa tugas seorang arsitek? Arsitek sebagai seorang perancang bangunan (building designer) namun peran arsitek tidak hanya sebatas bangunan saja, tetapi meliputi tugas penataan (penciptaan dan perwujudan) dari ruang dalam skala yang lebih luas.
Ruang tersebut merupakan lingkungan binaan (build environment) yang diperuntukkan bagi kehidupan manusia maupun masyarakt luas. Dalam skala kecil tugas arsitek menata ruang-ruang (space) yang diintegrasikan secara utuh dalam bentuk bangunan (building). Dalam skala kecil inilah arsitek menjalankan tugasnya sebagai perancang bangunan (building designer). Seorang arsitek akan berupaya secara maksimum dalam proses merancang bangunan sesuai dengan kaidah-kaidah dalam perancangan arsitektur.

Lapangan kerja arsitek tidak bisa lepas dari hal-hal yang bersifat "'kreatifitas". Karena arsitek harus mempunyai 'daya cipta' yang tinggi di dalam menyelesaikan tugas-tugasnya di bidang arsitektur, karena arsitek di dalam melakukan pekerjaannya tidak bisa lepas dari desain/perangcangan, sedangkan desain/perancangan sangat erat hubungannya dengan 'kreatifitas'. Namun demikian pekerjaan seorang arsitek sangat jauh berbeda dengan pekerjaan seorang seniman patung/seni instalasi/seni lukis. Karena proses desain adalah proses yang ilmiah karena melalui tahapan research dalam menyelesaikan konsep phylosophi dan konsep kultural sehingga dapat dikatakan bahwa hasil karya arsitek adalah hasil karya ilmiah yang kreatif. Oleh karena itu peran arsitek itu mau tidak mau pasti selalu lekat dengan hal yang bersifat 'kreatifitas'.

Di era pasar bebas nanti, seorang arsitek dituntut untuk bersaing dengan arsitek-arsitek asing yang menyerbu di Negara kita Indonesia ini. Jangan sampai arsitek Indonesia hanya sebagai pecundang, tidak mampu bersaing dikarenakan tidak/kurang kompeten. Sehingga kemampuan dalam mendesain/merancang yang kreatif itu yang menjadi tuntutan serius untuk diperhatikan agar kita mampu berkompetisi dengan arsitek-arsitek asing.



Gambar.2 Prinsip merancang bagi Arsitek

Hal-hal yang perlu diperhatikan bagi seorang arsitek didalam merancang adalah :

1. Fungsi (Function) 
Fungsi bangunan merupakan sesuatu yang harus diprioritaskan. Semua desain arsitektur apapun harus berfungsi dengan baik. Artinya, arsitektur itu harus bisa dipakai/digunakan sesuai dengan peruntukannya.

2. Bentuk/Estetika (Form)

Bentuk sangat berhubungan dengan estetika (keindahan), termasuk penggunaan warna, baik material maupun cat. Sehingga bentuk perlu dipertimbangkan untuk mendapatkan citra bagi bangunan itu.

3. Teknik (Technics)

Pertimbangan terhadap segi kekuatan bangunan. Karena teknik sangat erat hubungannya dengan kekuatan bangunan seperti struktur, konstruksi, elemen-elemen pendukung bangunan, dll.

4. Keamanan (Safety)

Pertimbangan keselamatan dan keamanan bangunan terhadap hal-hal yang menyebabkan manusia sebagai pengguna bangunan itu celaka, misal : terjadi kebakaran.

5. Kenyamanan (Comfort)

Pertimbangan terhadap kenyamanan bangunan perlu dipikirkan, agar bangunan itu membuat nyaman bagi penggunanya.

6. Konteks (Contexs)

Pertimbangan terhadap konteks lingkungan atau kawasan dimana bangunan itu akan didirikan, sehingga bangunan dapat selaras terhadap lingkungannya, baik lingkungan alam maupun lingkungan buatan.

7. Efisien (Efficient)

Bangunan itu harus tepat guna, artinya dapat digunakan secara optimal dan tidak mubazir.

8. Sustainable

Bangunan itu harus berkelanjutan, artinya ramah terhadap lingkungan sekitar dan tidak merusak alam.

\section{KESIMPULAN \& SARAN}

- Didalam menghadapi MEA (Masyarakat Ekonomi Asean), khusus untuk para arsitek/calon arsitek harus membekali diri dengan kompetensi seperti apa yang disyaratkan oleh Asean Mutual Recognition Arrangement on Architectural Services (MRA) sehingga membekali diri dengan Asean Architect (AA) Licency, agar dapat bersaing dengan arsitekarsitek asing yang masuk Indonesia.

- MEA identik dengan kreatif, artinya siapa saja di dalam bidang apa pun yang kreatif akan dapat survive, termasuk para arsitek Indonesia harus meningkatkan daya kreatifitasnya yang tinggi sehingga mampu bersaing dengan arsitek-arsitek asing yang masuk Indonesia, sehingga arsitek memang dituntut untuk selalu mengupdate kemampuannya didalam merancang. Makanya dalam program kegiatan IAI (Ikatan Arsitek
Indonesia) ada PKB/CPD ini dimaksud untuk meningkatkan kompetensi para anggotanya untuk menjadi arsitek yang handal.

- Mendesain tidak hanya sekedar menggambar yang hanya mengedepankan nilai-nilai estetika atau beautifikasi semata, akan tetapi di dalam mendesain, arsitek harus mengikuti prosedur kaidah dalam 'architectural design' yang benar sehingga sebenarnya proses desain adalah proses ilmiah. Disana arsitek dituntut untuk melakukan research. Karena didalam mendesain arsitek harus mempertimbangkan aspek fungsi, aspek bentuk, aspek teknologi, aspek keamanan dan keselamatan, aspek kenyamanan dan aspek kontekstual dan aspek efisiensi.

- Rancang bangun di negeri ini (Indonesia) akan baik jikalau punya undang-undang arsitek, karena dengan adanya undang-undang arsitek, para arsitek didalam merancang akan hati-hati, artinya akan mengikuti kaidah tata laku dalam perancangan arsitektur secara benar sesuai dengan norma yang berlaku.

\section{DAFTAR PUSTAKA}

Kenneth Frampton : Modern Architeture, Thames and Hudson ltd, London, 1997

Hasan-Uddin Khan : Contemporary Asian Architects, Taschen, Italy, 1995

Michael foster : The Principles or Architecture, mallard Press, NY, 1982

Naskah Akademik RUU tentang Arsitek, 2015

Buku Kode Etik Arsitek dan Kaidah Tata Laku Profesi Arsitek IAI, 2007 